\title{
Mutant City: On Partial Transformations in Three Johannesburg Narratives
}

\section{TIMOTHY WRIGHT}

The closing shot of Neill Blomkamp's District 9 pans out on the state bureaucrat Wikus van de Merwe, who has transformed into one of the insectoid aliens he was originally charged to evict, standing among the detritus of the "prawn" encampment on the outskirts of Johannesburg. The alien carapace that started growing on his left hand has spread such that he is outwardly indistinguishable from the aliens scavenging through the waste of "District 9." Yet despite this transformation, Wikus has not relinquished his identification with the human: in the final scene of the film we see Wikus fashioning a flower of scrap metal-a flower identical to those that have been mysteriously left on the doorstep of his wife. His intensely expressive gaze speaks of a pained longing, a lingering hope for a cure to his mutation (figure 1). Inside, he is still Wikus, not a prawn.

Wikus is the most recognizable of a range of posthuman creatures-mutants, hybrids, and assemblages coupling the human with the other-than-human-that have populated the South African imaginary in the postapartheid period. These creatures have contradicted the expectation that, once freed from the unnatural torsions of apartheid, South African artists would immerse themselves in a more fully human world. They are not entirely a new phenomenon: mutant forms can be traced back to Jane Alexander's famous Butcher Boys sculpture of 1985-86, in which human bodies are sutured onto bovine heads, and to Dumile Feni's 1987 sculpture History, in which a part-human figure of what Paul Clarke terms "uncertain species" is hitched to a wagon carrying human occupants (Clarke 14). Yet there is no doubt that these mutants have shifted closer to stage center, where they form a minor but powerful counterimaginary to a dominant South African poetics effectively constructed by a series of internationally acclaimed and morally serious white writers working in a broadly realist tradition: Olive Schreiner, Alan Paton, Athol Fugard, Nadine Gordimer, J. M. Coetzee. (The black literary tradition is a different matter, as I discuss in the conclusion of this essay.)

Hence Imraan Coovadia's observation, in an essay on the concept of transformation, that shape changing has not traditionally been a useful theme for South African writers. South African society, he argues, "emphasized verbal acts of interpellation, naming and fixing, and could hardly be expected to cope with the loss of

This essay was written while on a Mellon postdoctoral fellowship at the Wits Institute for Social and Economic Research (WiSER) from 2014 to 2016 and owes much to the vigorous intellectual environment fostered there by Sarah Nuttall and others. A talk by Rita Barnard, "Temporality as Narrative Infrastructure" (WiSER, May 2015), and an honors thesis by Nandi Weder, "Space in Transition: Alternative Forms of Agency and Power in Ivan Vladislavic's Portrait with Keys," both helped to crystallize my ideas (this thesis has since become a chapter in Weder's master's dissertation; citations refer to the former). My special thanks to Sarah Nuttall and Nancy Armstrong for their comments on drafts of this essay. 


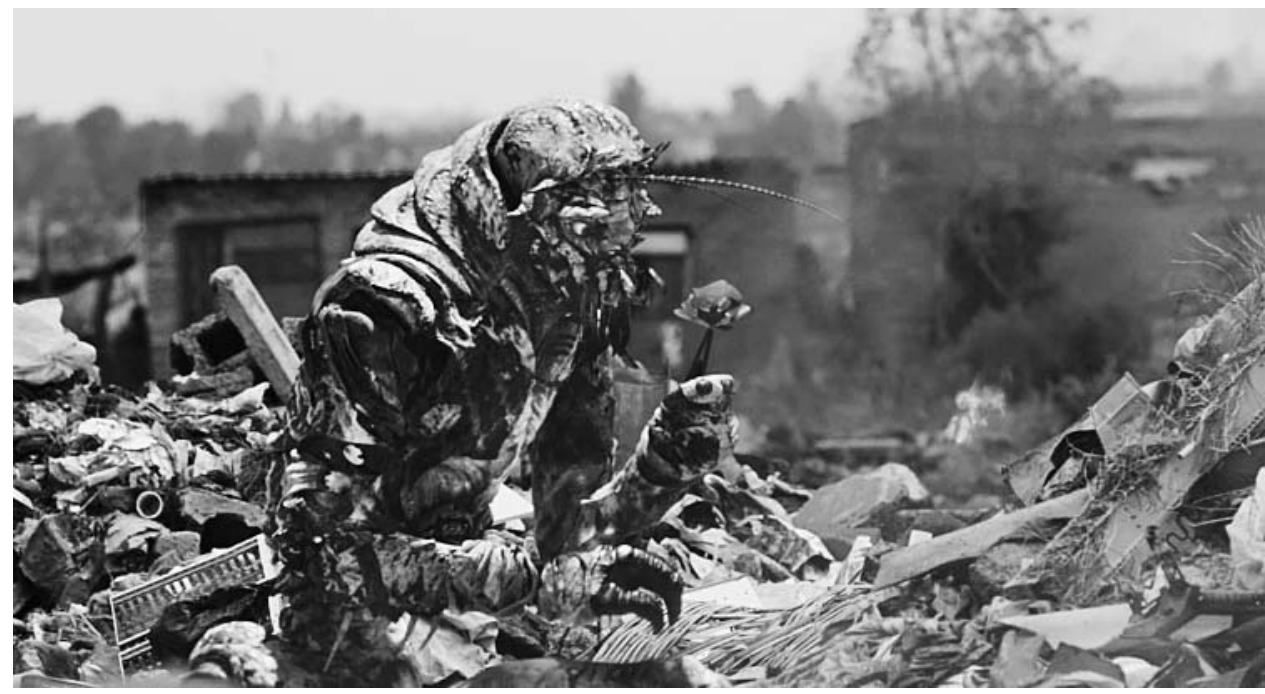

Figure 1.

name and identity consequent on one or more alterations in form" (56). With the passing of the apartheid state and the emergence of an era at least nominally committed to transformation, however, Coovadia implies that the theme might finally find traction: its attractiveness, as he notes, "depends on the promise of instability," a quality the postapartheid state possesses in abundance (57). As a narrative tool, transformation aims, in Coovadia's reading, at what I would call a reenchantment of the political: in drawing trajectories across seemingly rigid boundaries, the transfiguration of forms signals an "attempt to return the possibility of wonder and surprise to social process . . . and to suggest an endlessly productive future" (57).

Clearly a complete Ovidian metamorphosis is not represented in Blomkamp's film. The film ends with Wikus suspended between two worlds, unwilling to embrace an alien identity, unable to return to a human one. He is a "mutant": an organism that has undergone an unexpected and unpredictable transformation into something new, neither fully alien nor human. In this sense, Wikus embodies the kind of stalled temporality Coovadia intends when he speaks of the gap between an "intolerable present" and an "impossible future" (51). Yet in its binding together of two tropes, the radical transformation of the individual and the derelict and marginal spaces of the city of Johannesburg, the film suggests that forms of dynamism might lurk unseen behind its facade of stagnation.

In its violence, its messy incompleteness, its hint of a possible breakthrough to the new, and its lingering attachment to the former self, Wikus's mutation is emblematic of a series of partial transformations that take the stage in recent Johannesburg narratives. They are products of the particular kinds of imaginaries that cluster around postapartheid Johannesburg: on one hand, a city whose fractured, fragmented, and hostile spaces enjoin on the subject desperate forms of self-preservation; on the 
other hand, a city that has, like Wikus, mutated. This essay will suggest that these Johannesburg fictions centered on mutation constitute a subgenre that responds symptomatically to postapartheid Johannesburg. It will further suggest that the "mutants" who populate them are key to understanding political anxieties and desires in a postapartheid South Africa characterized by a simultaneous stagnation of historical movement and pent-up desire for radical change. The emergence of this trope signals a shift in focus away from the nation and the grand movements of its history to the viscous, piecemeal, sticky mutations of space, a shift from oppositional resistance tied to a narrative of liberation to another kind of resistance: a resistance to becoming mere matter. Large-scale historical change is not directly represented in these narratives; rather, transformations are individualized and haphazard, drawn down from the grand level of history and restaged within the multiple trajectories of individual lives.

In its everyday usage, mutant is a negative term with phobic, often racial, overtones. Let me therefore be clear about the specific sense in which I intend it, which concerns the disruption of trajectories of space or subjectivity. Mutation, in my terms, is an event effecting a radical and unforeseeable rearrangement of the human subject: an alteration that may either aid or diminish the organism's capacity to survive in a fundamentally hostile environment. On one hand, this loss of stable identity yields a phobically charged subject reduced to what Eric L. Santner has called "creatureliness": the heightened proximity to one's animal being. ${ }^{1}$ On the other hand, however, mutation is a locus for the emergence of the new. This creative potential within mutation is conceptually developed in the late nineteenth century through the evolutionary field of "mutationism."2 For mutationists, "evolution took place by sudden steps and that discontinuous variation was far more significant than continuous" (Bowler 275). The mutationists differed in many respects on the relationship of their theory to Darwin's, but they were united in thinking that mutation was the fundamental source of novelty in evolution. In Wilhelm Johanssen's development of the argument, Darwin's law of selection ultimately reaches a limit beyond which it cannot pass: genuinely new factors can be introduced into nature only via a sudden mutation altering the characteristics of an existing pure line (Bowler 270-71).

This evolutionary reading of mutation is of course to be understood metaphorically, as an unpacking of the possibilities inherent in mutation's logic of discontinuous transformation, which disrupts and reroutes what appear as settled trajectories. Mutation thus holds forth the prospect of a realization of possibilities that appear foreclosed from within the matrix of the existent: the reinvigoration of a stultified present rather than an escape from it into a past or future. But by the same

1 The creaturely, which Santner sees in the bent and downcast figures of Kafka and Sebald, cringe under the shadow of a catastrophic modernity. Under the continual threat of sovereign violence, they are reduced to an animal nakedness that "rivets" them to themselves, to use a term Santner borrows from Levinas (Santner 23). The figures I examine here all in various ways exceed the creaturely, and in so doing point to lines of flight from a stalled or exhausted modernity.

2 For an overview of mutationism and its relationship to Darwinian evolutionism, see Bowler 256-65. 
token, the anarchic logic of mutation delinks historical transformation from a set trajectory and telos. A mutation may yield nothing; certain transformations may indeed, as Coovadia notes, merely "give new forms to old kinds of exploitation and new legitimacy to old and unearned property" (57).

Mutation thus has a logical correlation with Gilles Deleuze and Félix Guattari's vitalist notion of becoming, which thinks not "in terms of relationships (between A and B)" but "in terms of production (from A to $x$ )" (234). "To become is not to progress or regress along a series," they state, for "[b]ecoming produces nothing other than itself" (238). Yet unlike becoming, the logic of mutation remains rooted in the possibilities and constraints of the physical body and the material world. In its emphasis on the material embodiment of the new, mutancy is also a distinct condition from Homi Bhabha's hybridity, that product of the coercive union of different cultures. If the hybrid subject emerges from a colonial environment as an interpreter and sly mimicker of the colonizer, "not quite/not white," the mutant subject has no necessary relationship to coloniality or to mimicry (Bhabha 92). It is a logic that is less germane to overtly colonial spaces than it is to marginal and decayed spaces in which ideological forces have ceded to material ones. ${ }^{3}$ The mutagen, the causal element precipitating mutation, is located in the material world that the subject inhabits-indeed, is even latent within the subject-rather than in an ideological realm that floats above it.

Hence the focus on the shifting landscapes of postapartheid Johannesburg, the locale of the texts I discuss below: Ivan Vladislavic's experimental urban chronicle Portrait with Keys (2006) and two narratives that effectively protagonize the city's mutancy by condensing it onto the human body, Neill Blomkamp's District 9 (2009) and Lauren Beukes's science fiction/urban fantasy novel Zoo City (2010). These texts can be understood to constitute an emergent and novel strand of "white writing" that has begun to employ themes of metamorphosis in ways that answer Njabulo Ndebele's call for "a shift in white identity in which 'whiteness' can undergo an experiential transformation by absorbing new cultural experience" (52). Yet, while the mutations they explore evidence in particular white South Africans' anxieties and desires regarding the nature of their future in South Africa, they at the same time bear witness to a more widespread understanding of Johannesburg as a space of mutancy, an arena in which human subjects either take on or resist the nonlinear logics of the city.

3 For Bhabha, hybridity emerges within the colonial episteme. "Hybridity," writes Bhabha, "is a problematic of colonial representation and individuation that reverses the effects of the colonialist disavowal, so that other 'denied' knowledges enter upon the dominant discourse and estrange the basis of its authority" (114). My argument is that the phenomenon of mutancy emerges more properly from the logic of global late capitalism, in whose decayed spaces and undersides it takes hold. This is not to say that mutancy is antithetical to the postcolonial; indeed, it may often run in tandem with it. The networks of late capital might of course be said to entail their own mode of coloniality, and mutancy might thus be understood as a counterlogic that responds to the decentralized networks described in Michael Hardt and Antonio Negri's Empire, where "struggles to contest and subvert Empire, as well as those to construct a real alternative, will ... take place on the imperial terrain itself" - via tactics of rerouting and rewiring (xv). Thus while Bhabha is interested in acts of enunciation and structures of reference and signification, I am interested in material bodies and things. 


\section{Johannesburg, Capital of Mutancy}

"A revolution that does not produce a new space," wrote Henri Lefebvre, "has not realized its full potential; indeed it has failed in that it has not changed life itself, but has merely changed ideological superstructures, institutions or political apparatuses. A social transformation, to be truly revolutionary in character, must manifest a creative capacity in its effects on daily life, on language and on space" (Lefebvre 54). Lefebvre's vision of a transformed city casts into relief the halting nature of Johannesburg's transitions. South Africa of course did not undergo revolution but a negotiated transition, and its past was not liquidated but incorporated into its present. At a material level, the spatial transformations in the wake of what Achille Mbembe calls the "collapse of the racial city" (62) have been piecemeal, halting, and most importantly_as Jennifer Robinson emphasizes (168)—unpredictable.

Since the fall of the apartheid regime, critical discourse on and popular imaginations of South Africa have focused with renewed intensity on Johannesburg: its schizophrenic social organization, its fragmented geography, its "citadelization," its "architecture of fear," and its development within networks of global capital, all indexes of the ultimate failure of the nation to move beyond its segregated past. I will focus here on Johannesburg's mutancy, a concept that foregrounds its temporal movements rather than its spatial calcification. To a large degree the story of postapartheid Johannesburg remains one of segregated spaces. "[T]he metamorphosis of Johannesburg from the exemplary apartheid city at the apex of white minority rule to the dominant metropolis of the new South Africa," writes Martin J. Murray, "has gone hand in hand with the emergence of new patterns of spatial unevenness and new kinds of social exclusion" (Extremes xv). The cityscape is thus structured by dualities, divided, according to Murray, into an "urban glamour zone" and an "urban danger zone" (quoting Saskia Sassen) with "island-like enclosures ... laid on top of an already distorted urban landscape divided along racial lines" (2-3). The inner city, largely abandoned by capital, comes in for the strongest criticism: the projects of apartheid's "reactionary modernism" now, in their decay, serve as repositories of immiseration, home to "a Darwinian social order permeated with conflict over, and competition for, scarce resources in a hostile environment" (150).

Murray's view of Johannesburg yields a city permeated by creatureliness. The inner city has been largely abandoned to the workings of natural history: law has little traction, civil society is fragile and fleeting, inhabitants are exposed to the traumatic dimensions of political power with little means to exercise power themselves. This reading of the city possesses great analytic power, yet it works almost exclusively from the perspective of what Michel de Certeau would call "strategy": the top-down logic and unilinear temporality of the city planner (xix). But the history of Johannesburg is not merely a history of the imposition of segregationist forms; it is at the same time the history of often impovisatory spatial practices that have countered or evaded these forms. This is the blind spot in Murray's portrait of the city: viewing human fates as products of Manichean macrostructures, it grants little import to the forms of life and agency that have taken shape in the interstices of the city. The aesthetic and nonnormative dimensions of the city are 
thus disfigured into, in the words of Mbembe and Sarah Nuttall, "nothing but the spatial embodiment of unequal economic relations and coercive and segregationist policies" (10).

Although Johannesburg's planning and development has always been informed by the drive to segregate and separate, it has never quite been the exclusive city it has imagined itself to be. Mbembe has written of the incompleteness of apartheid's attempts to colonize the city, characterizing the apartheid city in DeleuzoGuattarian terms as rhizomatic or "tubular," "a space made up of leakages, of several lines of flight that not only coexisted but intermingled" (47). We might then imagine the contemporary city as consisting of two spatial logics coexisting in an antagonistic and dynamic relationship. One, a rhizomatic city in which space is appropriated and repurposed in original and unexpected ways; another, an "official" arboreal city creating and preserving itself in the image of Western modernity, insulating itself from its encroaching other by means of an architecture of fear that takes the form of what some commentators have dubbed "citadelization": the endless proliferation of higher walls, electrified fences, gated communities, private security, neighborhood watches, the creation of fantasy spaces.

Apartheid policies, in their bid to maintain their fantasy of separate worlds, continually sought to plug leakages between these domains. In the postapartheid city, many of these plugs have come unstopped. This is most visible in the inner city, which has changed utterly from its former life. A part of the city that for approximately a century was recreated as "a visible extension of Europe" (Murray, Extremes 12) for its white inhabitants, was rapidly, over the course of the 1990s, fled en masse and became home to a very different population of largely impoverished black immigrants and small-business owners. To wander through the city center in the late 1990s and the 2000s was to see an endlessly mutating African cityscape amid the skeletons of the city's Euromodernist past. ${ }^{4}$ Rodney Place has described how the inner city's built environment has become detached from its original ideological aims and meaning. Due to this detachment, he says, "the modernist structures ... now exist in pure physicality, since their instructional intentions are redundant to people already social and urban in their habits" (335). What Place hints at here is the materialization of the inner city. Rather than setting out a series of normative forms of inhabitation, the built environment becomes a set of physical objects to be negotiated or repurposed, a natural rather than a cultural landscape. The city as a fully manufactured entity, as the product of human labor and planning, gives way to a space in which the boundaries between humanist notions of nature and culture lose their distinctness, in which decay morphs into renewal. This yields a different logic from Murray's reading of the inner city as "a shattered landscape," a "stalled modernity" that "failed to live up to its promise of perpetual vitality" (Extremes xiii). The long history of creative destruction that has characterized the inner city has now given way to the fundamentally nonlinear mode of what I will call mutancy, in which new forms sprout unexpectedly from the skeletons of the old.

4 For accounts of the postapartheid transition of Johannesburg, see Chipkin; Bremner (both from an architectural perspective); and Beavon (237-82). For a cultural history of the transition, see Kruger (150-234). 
Here spatial mutation-the repurposing of infrastructure to serve ends radically different from those for which it was designed-becomes the dominant logic of change. ${ }^{5}$ To foreground these mutant elements of the city is not to glamorize its suffering and impoverishment but rather to return the creative dimension of time to Murray's vision of its stalled spatial configuration. The texts I discuss below thus imagine not futures to which the leap of mutation might allow passage but rather transformations in the present that would reanimate the possibility of a future.

\section{Mutant Spaces}

Ivan Vladislavic's Portrait with Keys is one of the most thoroughgoing attempts to map out-from the perspective of a single inhabitant - the range of urban adaptations that have emerged as the city transforms and its idealized vision of itself breaks down. ${ }^{6}$ The text's central preoccupation is with how urban subjects make themselves at home in the alienness of a Johannesburg in flux, a city that comes to resemble, to borrow a phrase from Lewis Mumford, "the durable, concrete form" of war (Mumford 58). For Ivan, the writer-narrator of the chronicle, it is the acts of walking and writing that give him some sense of belonging to Johannesburg. Walking, unlike driving, exposes him to chance, renders him vulnerable, and places him in contact with the alterity of the city. Ivan laments that, unlike Dickens's London, Johannesburg resists narrativization. Yet this hostility to narrative inspires his own adaptation to the city: he returns from his walks bearing the 138 written snapshots that form the body of the chronicle. This narrative structure-navigable in multiple ways - both replicates the fragmentariness of Johannesburg and opens the reader's path through it to the workings of chance.

Gerald Gaylard suggestively reads the book as a "migrant ecology" that maps out the complex interplay of worlds of the city's inhabitants (287-307). I would push Gaylard's claim further: in its attention to the residual and the emergent cities occluded behind the official city, Portrait with Keys charts the trajectories of spatial change-the evolutionary forces behind the ecosystem. The narrator's seemingly self-absorbed nostalgia for the city's past is crucial to this view, since it foregrounds the dimensions of time and history that make this change apparent. Unable to feel fully at home in the transforming city of the present, Ivan's gaze becomes detached and anthropological. It is this gaze-attentive to the mutant spaces of the city and the human adaptations to which they point-that interests me.

5 Of course, the immense and chaotic transformations of fortified Johannesburg (primarily in the plush northern suburbs to which capital has relocated), driven by real estate capital, constitute their own form of mutancy, an attempt to resist the thingliness of the inner city's decaying structures. These mutations of enclosure, I maintain, are maladaptive or at the very least propose a future that extends the city's segregationist logic rather than rerouting or subverting it.

6 My reading of Portrait with Keys bears the influence of Nandi Weder's superb honors thesis on this text. Weder uses Fred Scott's theory of the three fates of architecture-destruction, preservation, and reappropriation-as a lens through which to read the book's representation of spatial transition in Johannesburg and the various tactics of urban habitation to which it gives rise. 
The adaptations fall into two basic classes: on one hand, forms of fortification designed to defend space and property and thus resist change. Of this first class, witness the "Hercules cacti," a mutation of the suburban garden hedge that consists of metal "cylindrical segments, fiercely spiked and barbed all the way round ... mounted horizontally on long axles fixed to the top of the wall" (32). The Hercules cactus is a weak form of mutation: not a disruption but an extrapolation of a three-century-long trajectory of the garden wall as excluding technology, beginning with Van Riebeeck's seventeenth-century hedge, planted to keep raiding Khoisan out of VOC (Vereenigde Oostindische Compagnie / Dutch East India Company) property.

Less familiar adaptations-and these we might consider stronger forms of mutation-are the forms of spatial appropriation and refunctioning that Ivan encounters. On one of his walks, Ivan lifts the iron cover of a water-main box on the street and discovers inside it a stash of carefully organized possessions:

a brown ribbed jersey, army issue; a red flannel shirt; a small checked blanket; two empty bottles_Fanta Grape and Lion Lager; a copy of Penthouse; a blue enamel plate; a clear plastic bag containing some scraps of food.... On one side, the empties have been laid down head to toe, the plate balanced across them to hold the food; on the other, the blanket has been folded, the shirt and jersey side by side on top of it, the magazine rolled up between. In the middle, behind a lens of misted glass, white numbers on black drums are revolving, measuring out a flood in standard units. (51)

The sense of flatness in this description is typical of the book's technique, where the confrontation with worlds of otherness is limned by an enumeration of things. One item in this typically dispassionate and pragmatic list startles: the Penthouse magazine, which points to an unexpected world of desire, fantasy, and sensuality. Placement of the magazine alongside the water meter, with its indifferent infrastructural management of nature, creates a flat juxtaposition that scrupulously avoids the kneejerk responses of either pity or romanticization, highlighting instead the opacity of these adaptations, the way they escape conceptualization within an inherited notion of the city. The image with which this vignette ends-of a man "gazing down into a well" (51)—captures this: the nature of the life existing in the depths cannot be discerned by the viewer standing at the surface-only the fact that it exists, or once existed.

In genetic theory, one speaks of loss-of-function, or amorphic mutations, and gain-of-function, or neomorphic mutations. One could read the mutations in the text along this axis, in which the nostalgic and fortified subjects of the city gradually lose their ability to fully inhabit it, and those inhabitants of the marginal, rhizomatic city, by repurposing its tools, gain something-often merely the means to survive, but sometimes the means to flourish. An instance of the latter appears in Ivan's discussion of the "urban poacher" (136). Ivan (137) quotes the urban theorist AbdouMaliq Simone: "There are young people in Johannesburg who spend twelve and more hours a day simply passing through different neighbourhoods ... seeing what can be taken easily, but also running into others like themselves, who pass along information and impressions, sometimes teaming up to do 'jobs,' sometimes 
steering each other in the wrong direction" (Simone 186). Simone's descriptions hint at a complex economy based on a nomadism in which neither place nor subject position is ever stable.

As Nandi Weder observes, Ivan views crime-at least petty crime-not as a scourge but as an inevitable component of the city's transformation. Indeed, crime is partly naturalized through Ivan's language, as he embellishes Simone's analysis through the trope of the city as nature reserve: the urban poacher, he writes, is now taking advantage of "open season" (Vladislavic 136). Poachers have hacked away at Herman Wald's Leaping Impala sculpture, a bronze steenbok, a horse, and a pair of eagles in addition to assorted water mains and manhole covers. Disembodied pieces of these sculptures have turned up at scrap metal dealers and pawnshops. Here the elements of the monumental city-public sculptures-are dissolved into heads, limbs, tails, and other parts, and, as Weder suggests, enter into an economy of circulation in which their value is rearticulated and their function transformed. Rather than culminating in the fixed product of the sculpture, the materials of the city continue to shift form as they reenter the urban economy.

A unilinear narrative of the city's "rise and fall" yields here to a more complex and layered set of histories without a single subject or telos. What is the ultimate trajectory of these mutations? How are they to be understood or narrated? The forms of mutation Ivan charts are continually recaptured as extrapolations of the past rather than eruptions of the new. The trajectory that runs from hedge to Hercules cactus, like that from cattle raider to urban poacher, seems to form a direct line. Is this because the city itself is locked within an impasse in which mutations serve merely to repeat and reinscribe the past? Or is it rather that the text's lexicon and frame of reference are drawn from the past-that it cannot find the language that will do justice to the mutations' newness?

This sense of stalledness might explain why, despite the open forms of navigation it offers through its narrative, there is little sense of temporal movement: one feels one is wandering through frozen spaces. The text seems always on the verge of breaking through to an apprehension of the new only to stop at the threshold. Perhaps the sense of isolation that pervades the text stems from a sense that, despite Ivan's attempts to break free of perceptual and spatial strangleholds, the city is growing away from him and eludes his attempts to catch up with it. At a symbolic level, the direction of exclusion is thus reversed: Ivan's traversals of the city are dogged by a sense of lack. We can return here to the urban poacher: this figure is in some ways the double of Ivan, who wanders the city in search of writerly loot. But while Ivan's movements around the city are carefully chosen and choreographed anthropological sorties, the urban poacher's roaming is practical, an adaptation geared to an environment he must master in order to survive. And while the urban poacher seems to play an integral part in the emergent mythology of the city, Ivan's wanderings come to seem peripheral to its workings.

\section{Mutant Bodies}

Vladislavic's mapping of a world of mutancy, of radically discontinuous adaptations emerging from the shifting forms of an urban world, sets the scene for two 
speculative metamorphic narratives, in the film District 9 and the novel Zoo City, that imagine journeys across the boundaries over which Ivan merely gazes. These mutations provide a mechanism via which the privileged subject is made to enter the world of the uncanny "other," and in this sense they are radicalizations of the kinds of perceptual shifts enacted by Portrait with Keys, precipitated by collisions of ostensibly separate strata of urban life. But they offer more than just new perspectives: they explore new embodiments. These mutants must learn to creatively adapt in order to survive-adapt not only to the new environments they are driven to inhabit but also to their own new bodies.

Jayna Brown has remarked on the "embrace of decay" in the aesthetic fabric of both these texts, which she argues serves as a metaphor for a "disintegrating ideology of colonial whiteness" (7). I would alter her prognosis slightly: the abject and decayed in these texts are not just spaces of disintegration but also of (possible) transformation, both terrifying and liberating, into forms of posthuman subjectivity. Here it is useful to point out these works' inheritance from science fiction. It is no coincidence that these two dominant works of postapartheid South African speculative narrative are both set in the city of Johannesburg, both inhabit a present rather than a future, ${ }^{7}$ and both deploy mutation as a central trope. This signifies an important departure from conventions of the genre. Both narratives imbue a realistic Johannesburg with supernatural mutagenic elements whose effects are developed with what Darko Suvin would call "scientific" rigor (6). However, rather than imagine a future (science fiction) or a past (fantasy) from which the present will appear defamiliarized, they both instead imagine ruptures within the present. What Suvin calls the "narrative novum" of the science fictional text is not contained in a remote enclave or consigned to a distant epoch (3). Instead, it emerges from spaces within a present-day metropolis as an aesthetics of, as Blomkamp puts it in his director's commentary on District 9, "the fantastic in the mundane." The two texts are science fictions of the present: their concern is with mechanisms of change rather than with extrapolations into a future, with eruptions of otherness through the surface of the everyday. ${ }^{8}$ Large-scale changes and potentials are imagined through condensation onto the manageable form of the human body, which possesses a plasticity and suppleness that history does not.

A few brief comments on District 9, a narrative that explores the various forces by which transformation is constrained, resisted, or denied. The film amplifies the Manichean aspects of Johannesburg, viewing it as a space of rigid distinction rather than flux. This is apparent in the way the film restores the inner city to the gleaming apartheid-modernist grandeur of the 1970s and 1980s (now presided over by the multinational conglomerate MNU, housed in a glittering and refurbished Carlton

7 The alien ship in District 9 arrives in 1982, but the events of the film occur between 2010 and 2012.

8 Indeed, it may be more accurate to view them as gothic impersonating science fiction: their fascination is with elements of excess and instability latent within the modern subject. In this sense, they could be read as emerging from a strand of gothic writing-exemplified by works such as Frankenstein - that give bodily form to the phobic exclusions of the self-policing liberal subject. 


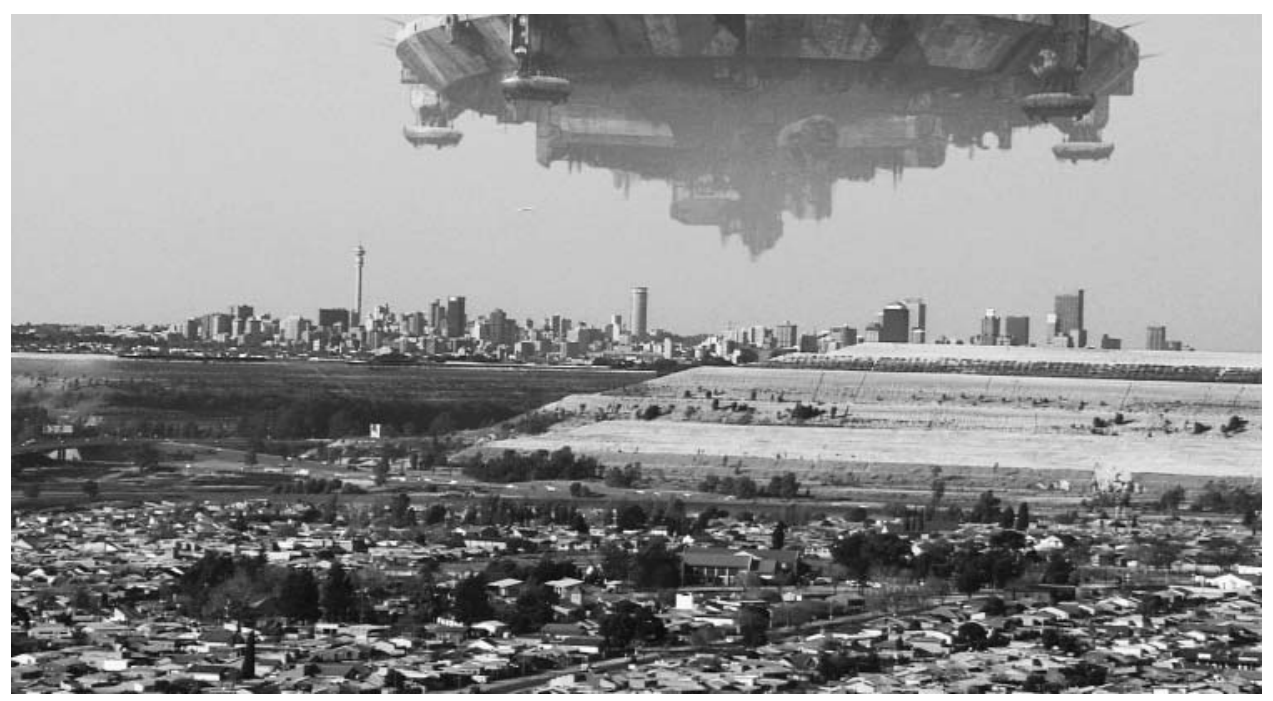

Figure 2.

Centre) and in its overlaid historical referents: distinctive yellow mine dumps, markers of the city's early extractive history; the forced relocations of the apartheid years alluded to in the title; the xenophobia of the postapartheid era; and, to cap it off, a middling, hide-bound Afrikaner functionary as protagonist. We are in a temporality of stuckness, of the eternal return of a past that has not been overcome.

Amid all this, an immense abandoned alien craft hangs suspended over the city, its pauperized inhabitants confined to a slum-like settlement below. The alien arrival is effectively a world-historical event held in abeyance: in the film's arresting opening scenes, the hovering silhouette of the alien city forms an inverted mirror of the Johannesburg skyline, inviting speculation as to what might happen when or if these two worlds fuse (figure 2). The film's narrative power hinges on the revelation that the stasis is illusory. One of the aliens has been collecting, from the debris of their settlement, fuel that will allow them to reignite their spacecraft and return to their home planet. Wikus's mutation disrupts these plans. In his intrusion into the alien world, he sprays himself with this fuel and contracts the alien "virus." From this point onward, the fates of both Wikus and the alien refugees depend upon the recovery of the fuel. This plot point entangles his fate with that of the aliens and sets up the stark choice he must make between his own future and theirs.

District 9 plays on an anxiety about the rupturing of bodily integrity through the mutational energies released by the alien fluid, and in doing so it revels in the transgression of an inviolable whiteness embodied in the person of Wikus. ${ }^{9}$ The camera's tracking of the mutation's inexorable progress through Wikus's body,

9 For a brilliant reading of the film's treatment of race, see Andries du Toit. Du Toit observes that the film, through its introduction of a viscerally other alien body, places the viewer in the mind of the racist: it "trips us up by making the racist gaze our gaze." 
with its panoply of ever-new horrors interspersed with moments of cognitive and empathetic breakthrough, might draw attention away from the questions around historical transformation raised by the film's ambiguous ending. How will the human-prawn conflict resolve itself? Will the aliens return to "fix" Wikus, thus restoring a species binary? Will they, rather, destroy or enslave the human race, who have, it emerges, subjected prawns to medical experiments and used them as military targets? Will they simply wash their hands of planet Earth, leaving the remaining prawn population confined to camps indefinitely? As John Marx writes, the film "relegates transformative change to the realm of utopian fantasy, the return of the king in the unwritten possibility of the movie's sequel" (166). While in his individual person Wikus might offer a bridge between human and alien life-the possibility of a single human becoming, briefly, something elseat a historical level we find a desolate set of possibilities that leaves little room for rapprochement between these two forms of being.

\section{Entangled Subjects}

It is Zinzi December's mutation in Zoo City that I want to focus on as a figure for a more plastic and creative approach to mutancy than the dead-end at which Wikus finds himself. Zinzi accepts and embraces the discontinuities of her mutant state, adapting to her body's transformation rather than resisting it. Unlike Ivan, continually thrown back into the past, or Wikus, waiting for a future that might return him to his former self, Zinzi inhabits an almost pure present (albeit one haunted by fragmentary flashbacks). The novel has been criticized for the way it makes plastic the varied spaces and histories of the city, melding them together without concern for their particularity (Sofianos 116) and collapsing complicated histories into a flat amnesiac present (Brown 8). But this is precisely the point: in these moments-and in its fast-paced, plot-driven narrative in general-the novel imagines an occupation of the city that is delinked from its histories, an inhabitation of time shorn of nostalgia, in which the dark history attached to Zinzi might be repurposed and take on a different meaning.

The novel's turn away from large historical movements toward individual fates is evident in its key differential logic: not race or class but the existential condition of what the novel vividly terms "aposymbiosis": the psychic tethering of human and animal. (There is also a third entity involved: a shavi, a spirit ancestor that endows magical abilities and functions, as Cheryl Stobie notes, as the utopian compensation for the animalling). With its biological overtones, the term aposymbiot captures the intimately entangled quality of these new human-animal assemblages. Although not physically connected (apo: away, apart), animal and human must now live in strict physical proximity to one another (symbiosis: living together). Should the animal die, the human will be consumed by the annihilating force of the Undertow; should the human die, the animal will fall into a profound malaise.

Before her mutation, Zinzi is a successful journalist living the high life in Johannesburg. After her brother is shot dead at her side in what appears to have been a drug deal gone wrong, she is "animalled" with a sloth and finds her way 
into the unpoliced, violent, and semicriminal community of others who have been animalled-called "zoos" —in Hillbrow, known colloquially as Zoo City. Because zoo inhabitants are perforce immigrants rather than locals, there is no sense of a rooted community or shared social norms but rather a set of shifting alliances. Here Zinzi has honed fiercely individualistic survival traits, developing a tough, sarcastic exterior that wards off the possibility of bonding closely with others. She squats in a derelict building neighboring the iconic Ponte Tower with her lover, a fellow zoo who is a refugee from the Congo, and scratches out a meager income as a "finder of lost objects" and a con artist; other zoos find different ways to survive.

The novel thus situates itself at an epicenter of "mutant" Johannesburg: the inner-city areas semiabandoned by the state and left to their own devices. The choice of once bohemian, now derelict Hillbrow is important not just for its reputation as a hub for impoverished immigrants to the city. Of all of inner-city Johannesburg, Hillbrow most embodies the phobic suburban relation to the city. By way of its landmark, Ponte Tower, a symbol of the inner city looming over every representation of Johannesburg, Hillbrow is figured not as the heart of the city but as an abjected entity that contaminates the body but cannot be fully dissociated from it: the dumping ground, as Murray puts it, for the "waste of city life" (Extremes 144). Zoo City is thus to the suburbs as the animal familiar is to the animalled subject: the phobic and disavowed other.

The aposymbiotic mutations in Zoo City occur as a kind of cosmic recalibration for an individual zoo's involvement in the death of another person: animals are the external manifestation of the zoo's guilty conscience and effectively brand the zoo with a living scarlet letter. This overlay of guilt and shame marks the distance of these animal familiars from the animal "dæmons" of Philip Pullman's The Golden Compass, where they function, as Marina Warner puts it, as an "external soul," the expression of the person's innermost being (Warner 206). In Zoo City, the animal is something different: with a few exceptions, it bears no obvious formal relation to the nature of the human to whom it is attached. Zinzi's sloth, for example, seems to have little to do with the hustling, bustling character we encounter, and other animals appear completely arbitrary: the Maltese poodle attached to the novel's most scheming, amoral character, the penguin attached to an Afghan warlord, the death row inmate animalled with a butterfly. These strike one as cosmic jokes, their lack of meaning a part of the punishment they inflict. Indeed, there is something Dantesquely punitive about the animalling: in return for having taken a life, the person responsible is now shackled with the care of a living being with whom their own destiny and mortality are irrevocably entangled. The zoo-animal mutant is not a hybrid but a relationship of existential interdependence between disparate beings. While Pullman's animal familiars place humans in a relationship with their spiritual and ethical being, Beukes's animals place them in a relationship with their animality: their physical existence, their drive for self-preservation, their capacity to suffer and die.

There is thus a strange vitality permeating the world imagined by Beukes, connected to the way these animals seem to gradually lose their shameful connection to a criminal past. The human-animal assemblage comes instead to produce a complex human intersubjectivity in which each organism can sense the 
affective state of the other. Moreover, they assist each other to survive: Zinzi uses her sloth's claws to slash at a pursuer's face as she flees through a warren of storm drains under the city; later, as she loses her way, "[s]loth guides [her] through the dark, squeezing [her] shoulders like handlebars" (213). These human-animal configurations evince the novel's move away from a humanist ontology based on the preservation of identity and its development over time to one that admits of radical discontinuities. Indeed, aposymbiot subjectivity fundamentally undercuts the monadic and autonomous subject of the official city. Rather than stabilizing the individual, animalling is an event that disrupts what Catherine Malabou calls the "snowball" of individual identity (Ontology 2). To be animalled is to be forced, at pain of annihilation, to accept as an intimate companion an absolute other. Witness the scene in which the teen pop sensation $S^{\prime} b u$ is forced to accept a crocodile familiar:

The Crocodile suddenly bursts forward, its belly rasping over the concrete, snapping its jaws at the Undertow, sweeping its tail through the thick black... . S'bu screams as the reptile lunges for him. But it's only moving to lean its massive head against his leg in something like affection. Horrified, he tries to shove it away. The same way I did with Sloth, until I realized he was the only thing between me and the rising dark. (339)

If the constitutive activity of the "official" Johannesburger is the building of wallsthe assertion of autonomy through the erasure of an outside-animalling collapses these walls in ways that radically rework ideas of how the human subject dwells in the world. Notably, it is not just humans who are cast out of a secure space: it is also the animal and the spiritual shavi, the latter the ghost of an ancestor who has not found a home in the afterworld. The aposymbiot assemblage thus embeds within itself a microfuture that breaks from the personal pasts of its constituent elements: the homes these animals and their humans make for themselves have nothing to do with a return to a fixed safe space.

Thus emerges an intensely physical involvement with the built space of the decayed city, which Zinzi occupies in a radically different manner from Ivan. Crucially, she does not possess the ability to choose her routes at leisure but is impelled by existential necessity, as in her flight from a police raid on her flat: "By the time the cops hit the kitchen with its ripped-out pipes and smashed sink, I've already dropped through the hole in the floor in the second bedroom, into 526. But instead of taking the main stairwell, I cross the walkway, climb through the window of Aurum Place's 507, clamber down the broken fire-escape and drop the last half-storey to the street" (310). Unlike Ivan, Zinzi is embedded within the material world of the city, an extrusion of it rather than an interloper into it. Notice her repurposing of the ruined space-the hole in the floor-as a means of enhanced mobility. The city becomes a material space that needs to be mastered and used rather than contemplated. While Ivan walks, Zinzi climbs, drops, runs, fights, and more than once swims through sewers under the city.

In these moments of spatial transgression-recalling innumerable Hollywood action sequences in which an overweening cityscape is mastered via physical traversal- the novel might validly be accused of turning the city into a video game. 
While Zinzi's acrobatics might bear little resemblance to actual inner-city life, in her plastic adaptations to her mutant state-and by extension to the city-she functions symbolically as the obverse of the cocooned suburban subject. One such subject is embodied in the novel's villain, Odysseus (Odi) Huron, a music mogul living in a rambling mansion in the wealthy suburb of Westcliff who attempts to retain the trappings of his plush former life and suppress his mutation. Secretly animalled with a giant albino crocodile that he keeps hidden in his garden swimming pool, Odi has organized a series of murders in order to kidnap the animals of zoos for use in a muti ritual (muti refers to African traditional medicine) that will delink him from his own reptilian coupling. In the course of this gory procedure, Odi does successfully separate himself from the beast, which, its bond with its human severed, promptly proceeds to devour him. Odi, in his attempt to reclaim his fortified suburban autonomy, to return home like his mythical Greek namesake, pays with his life. Odi possesses the rare animal that does appear to refer unambiguously to his essence: the albinism of the crocodile hints at Odi's excessive whiteness, his fanatic attachment to an airtight monadic subjecthood.

\section{Imagining the New}

Of course, for its black inhabitants, Johannesburg, with its racial zoning, forced removals, curfews, and pass laws, has always been a place of discontinuity, and in that sense the above texts should be considered belated arrivals to an image of the city long mined by black writers from the 1950s to the present day. This black writing of urban discontinuity is, moreover, highly attuned to the subtle and overt forms of dehumanization that haunt nonwhite subjects in the racial city. Indeed, in writing by Can Themba, Bloke Modisane, Miriam Tlali, Don Mattera, and others, the black urban subject is in a continual battle against a degrading bestialization. ${ }^{10}$ I do not want in any way to suggest that the texts I examine in this essay, by thematizing mutation and creatureliness, participate unthinkingly in the tradition of the dehumanization of the black urban subject. Rather, without reducing these texts to mere instances of what Coetzee has called "white writing," I would propose instead that the sudden appearance of the mutant from this long history of Johannesburg literature arises from a desire to disrupt trajectories of whiteness, of disembodied forms of subjectivity, and to imagine for it some unrecognizably altered future in which it is reimmersed in materiality. In an interview, Beukes stresses the importance of understanding the physical dimensions of the human subject and gives this an ethical significance: "The idea of the singularity, of minds living in virtual space, disembodied, appals me. Physicality makes us human, makes our lives relevant, forces us to give a damn, even while we shut ourselves away in

10 A full engagement with this topic is well beyond the scope of this essay. But for literary examples, see Bloke Modisane's Blame Me on History (1963); Can Themba's Requiem for Sophiatown (collected stories from the 1950s and 1960s); Don Mattera's Gone with the Twilight: A Story of Sophiatown (1987); and Miriam Tlali's Footprints in the Quag: Stories and Dialogues from Soweto (1989), all written in the apartheid period. The theme is less pronounced in the postapartheid period, but see Phaswane Mpe's Welcome to My Hillbrow (2001); Kgebetli Moele's Room 207 (2006); and Nthikeng Mohlele's Small Things (2013). 
our cosy middle class lives and try to ignore the bad stuff going on around us." Mutations force the human subject into a different space and in doing so into a heightened sense of the body, its integrity now seen as susceptible to radical forms of compromise by otherness. Perhaps the larger movement at play in these narratives of mutation is a turn to seeing the urban subject not in a humanist sense, as a citizen of the city, nor in the modernist sense, as an autonomous being occupying a rationally planned space or a communal machine, but rather in a posthumanist sense, as a physically precarious organism trying to make a home within a material world. This posthumanist city is pervaded by an urban nature that has nothing to do with the introduction of decorative greenery into the city but emerges instead in the breakdown of the city as a symbolic totality and in the infiltration of a naturalist, quasi-Darwinian logic into its idealized conception. ${ }^{11}$

Hence the unstable allegories of these narratives, which continually prod one from the stable domain of transcendent meanings into the shifting thingliness of the everyday urban world. These works thus move away from the melancholy allegory theorized by Walter Benjamin in The Origins of German Tragic Drama and employed to such great effect in the South African novel by Coetzee. As glossed by Santner, allegory, for Benjamin, was the symbolic mode proper to societies in transition. When the symbolic worlds of these societies no longer self-evidently explained the world, stability now had to be provided by way of reference to a transcendent world above things. Allegory thus made visible the constructedness of meaning and hence exposed the ultimate creatureliness of the human subject and the fragility of human symbolic systems.

In the texts I have discussed, something else is happening: a vitalist, metamorphic world continually collapses and overruns the scaffolding of allegory. Rather than summoning the irremediably catastrophic modernity of Benjamin, these worlds link up with a line of thought that asks how forms of newness emerge into the present. Malabou in particular approaches the question from a resolutely materialist perspective. ${ }^{12}$ Her writings on plasticity focus on the flesh and consequently take into account the traumatic dimensions-the wounding, the healing of the wound, and the scarring that remains-at play in transformation. In the essay "The Phoenix, the Spider, and the Salamander," Malabou proposes three "paradigms" by means of which one could imagine the recovery from trauma-which is, indeed, the movement of history itself. In the paradigm of the phoenix, drawn from Hegel, "regeneration is resurrection": the spirit "returns to itself from extreme rending" and is reborn over and over, each time identical, leaving no scar (Changing Difference 74-75). In the paradigm of the spider, which Malabou links to deconstruction, the

This entity might call to mind Simone's claim that the African urban space is better described not in terms of the city but as a "densely localized conglomeration of ethnicity, histories of settlement, and estates colliding with one another or coexisting in an uneasy truce" (175).

12 This is not to suggest a world of inert essences, for, as Malabou puts it, "Everything starts with metamorphosis" (Changing Difference 139). Malabou sketches out a human subject, drawn from discoveries in the neurosciences, that is fundamentally malleable. This subject is not merely the passive recipient of a subjectivity but part of an unfolding transformation in which the subject both creates and receives form. 
model is writing rather than resurrection. In writing, presence can never be fully recovered, but in its place a web of text is created, bearing witness to the scars of "the impossibility of reconstituting the origin" (77). In the paradigm of the salamander, Malabou's own figure, Malabou focuses on the way the salamander regenerates its tail if it is cut off. Each regeneration is slightly different: the tail might be smaller, for example, or differently shaped. The salamander represents "not a reconstitution of presence, but rather a regeneration of difference" (83).

If I may be schematic, I would ally the paradigm of the phoenix with District 9 , in which the new is imagined, if it is to be possible at all, in the form of a historical rupture that destroys and displaces the old. I would link the spider to Portrait with Keys, in which the new is imagined to be an endless series of variations that play upon and destabilize the old, while the old in turn returns to destabilize the new. The salamander, Malabou's figure for a newness that builds upon a wound in the old, restoring it with a difference, comes closest to the mutations of Zoo City. Unlike the phoenix, the salamander is a mortal organism, and its recoveries are based on "a finite survival, a momentary resource" (Changing Difference 83). This is indeed the case in Zoo City: the novel does not propose grand futures but rather micro futures that might enable forms of survival, without the hope that these forms will persist and ground themselves in history.

Yet these texts supply an element that all three of Malabou's figures lack: a logic by means of which the present breaks in some unforeseeable way from the past. Zoo City proposes a salamander that, rather than growing a new tail, grows instead a new head belonging to a different animal. A being with two heads: not a shift in subjectivity but in the notion of what it means to be a subject, now entangled with other living beings. The entangled subjectivity of the aposymbiot makes literal Bruno Latour's claim that, counter to the dominant myths promulgated by modern philosophy and science, "[t]o be a subject is not to act autonomously in front of an objective background, but to share agency with other subjects that have also lost their autonomy" (5).

Latour's insight can help us understand the re-enchantment of the political to which I made reference at the start of this essay. Our distorted concept of the autonomous subject arises, says Latour, because we are beholden to an Enlightenment myth that the human subject lives in a "de-animated world of mere stuff" (8). Under the spell of this naive rationalism, causality and change are stripped of their drama: "The concatenation of causes and consequences . . . does not trigger any dramatic effect," because "the consequences are already there in the cause: no suspense to expect, no sudden transformation, no metamorphosis, no ambiguity. Time flows from past to present" (11). The mutations of Zoo City follow Latour in reenchanting this conception of change, making "metamorphosis" not the outcome of a deliberate act but rather a "phenomenon that is antecedent to all the shapes that will be given to agents" (Latour 15). In doing so, the novel turns away from the grand linear movements of national history to imagine multiple different presents that might infiltrate the future in unpredictable ways. It does not imagine a new world but rather a motor by means of which new combinations of life emerge from within the matrix of the present one. Its very recognizable human subjects now open onto a range of previously inconceivable possibilities. 
In this respect, these works, for all their shortcomings-not least the risk they run of replacing the precipitous otherness of the city with a commodified image of the mutant-lay down tracks to a literature that might no longer be delimited by antithetical white and black lifeworlds. At the very least, it is an indication that white South African writers are emerging from the long shadow cast by Coetzee (himself the culmination of a long tradition of anticolonial white writing beginning with Schreiner) and are instead hitching their wagons to a resolutely materialist strand of black urban writing, a world in which flux, not stasis, is the constant. One important point, though, on which this Johannesburg fiction differs from its black counterpart is in its relation to the human. While black writers, excluded by both the theory and the practice of apartheid from the category of the fully human, have generally sought ways of salvaging a humanity from the discontinuities of urban environments, these white writers intimate that a form of freedom might be found by moving outside the confines of the human. Although the genre of mutant literature might promise to grant those with a settler identity an "African" future, it might ultimately put up for grabs what it means to be African. As a concept, mutation displaces notions of identity and "the human" and offers, in their place, something that has to be named anew at every instantiation.

Let me return here to the moment in District 9 when, hiding from authorities in the prawn encampment, Wikus enters the Nigerian enclave. Much criticism has rightly been leveled at the film for its treatment of the Nigerians, the only humans to willingly inhabit the prawn encampment. The Nigerians have set up shop in the encampment and exploit the aliens by selling them the cat food they crave in return for armaments. Moreover, they practice black magic and are not above devouring alien parts in a bid to take on their power; as Ato Quayson notes, they exist in excess of reason. ${ }^{13}$ Yet despite this, the Nigerians represent a possibility proscribed everywhere else in the film. Upon seeing Wikus's mutated arm, the ganglord's immediate impulse is one of desire: "I want that fucking arm!" he proclaims. He possesses an attribute that nobody else in the film does: a fearlessness about becoming other. ${ }^{14}$ In stigmatizing the Nigerians as comically amoral figures, the film forecloses this desire. Perhaps we need to isolate this desire to become other as the film's occluded utopian moment.

13 Ato Quayson reads the film as producing an image of Nigerians as more "other" than the prawns, since some prawns possess an ethical sensibility, while the Nigerians, the truly "unthinkable" others of the film, merely crave power. "The prawn leader," notes Quayson, "is first and foremost a scientist, but one with a highly developed social conscience." "The problem with the Nigerians' quest for mastery, however, is that it is shown as being mediated through black magic (the cannibalism) and thus is essentially the marker of a moral and intellectual deficit. We see then that in the social imaginary of District 9 it is the Nigerians that are the true Other. The prawns are only partially so, because they are shown to possess superior 'human' characteristics of familial love, reason . . . and political consciousness."

This argument emerges in the discussion thread of Du Toit's "Becoming the Alien." 
TIMOTHY WRIGHT is an assistant professor of English at Bilkent University, Ankara, and a research associate at the Wits Institute for Social and Economic Research (WiSER) at the University of the Witwatersrand in Johannesburg. He has published on, among other subjects, J. M. Coetzee, Kazuo Ishiguro, and numerous aspects of contemporary cultural production in Johannesburg.

\section{Works Cited}

Alexander, Jane. Butcher Boys. 1985-86. Mixed media. South African National Gallery, Cape Town.

Beavon, Keith S. O. Johannesburg: The Making and Shaping of the City. Leiden: U of South Africa P, 2004.

Benjamin, Walter. The Origins of German Tragic Drama. Trans. John Osborne. London: Verso, 1998.

Beukes, Lauren. "Interview—Lauren Beukes." Kgogomodumo Blog, 15 Aug. 2011 < https:// kgogomodumo.com/blog/2011/08/15/interview-lauren-beukes/ > .

—. Zoo City. Nottingham: Angry Robot, 2011.

Bhabha, Homi K. The Location of Culture. London: Routledge, 1994.

Blomkamp, Neill, dir. District 9. Sony Pictures Home Entertainment, 2009.

—. Director's commentary. District 9. Sony Pictures Home Entertainment, 2009.

Bowler, Peter J. Evolution: The History of an Idea. Berkeley: U of California P, 1984.

Bremner, Lindsey. Writing the City into Being: Essays on Johannesburg 1998-2008. Johannesburg: Fourthwall, 2010.

Brown, Jayna. “Celebrating the Abject." American Book Review 34.2 (2013): 7-8.

Certeau, Michel de. The Practice of Everyday Life. Berkeley: U of California P, 2011.

Chipkin, Clive M. Johannesburg Transition: Architecture and Society from 1950. Johannesburg: STE, 2008.

Clarke, Paul T. "Of Animals and Others: Life, Histories, and the Anthropocene in Johannesburg Science Fiction." Johannesburg Salon 10 (2016): 14-20.

Coetzee, J. M. White Writing on the Culture of Letters in South Africa. New Haven: Yale UP, 1990.

Coovadia, Imraan. Transformations: Essays. Cape Town: Umuzi, 2012. 
Deleuze, Gilles, and Félix Guattari. A Thousand Plateaus: Capitalism and Schizophrenia. Trans. Brian Massumi. Minneapolis: U of Minnesota P, 1987.

Du Toit, Andries. "Becoming the Alien: Apartheid, Racism, and District 9." A Subtle Knife (blog), 4 Sept. 2009 < https://asubtleknife.wordpress.com/2009/09/04/science-fictionin-the-ghetto-loving-the-alien/ > .

Feni, Dumile. History. 1987. Clay. Johannesburg Constitutional Court Art Collection, Johannesburg.

- History. 2003. Bronze. Johannesburg Constitutional Court Art Collection, Johannesburg.

Gaylard, Gerald. "Migrant Ecology in the Postcolonial City in Portrait with Keys: Joburg and What-What." Marginal Spaces: Reading Ivan Vladislavic. Ed. Gerald Gaylard. Johannesburg: Wits UP, 2011. 287-309.

Hardt, Michael, and Antonio Negri. Empire. Cambridge: Harvard UP, 2000.

Kruger, Loren. Imagining the Edgy City: Writing, Performing, and Building Johannesburg. Oxford: Oxford UP, 2013.

Latour, Bruno. "Agency at the Time of the Anthropocene." New Literary History 45.1 (2014): $1-18$.

Lefebvre, Henri. The Production of Space. Trans. Donald Nicholson-Smith. Malden: Blackwell, 1991.

Malabou, Catherine. Changing Difference: The Questions of the Feminine in Philosophy. Trans. Carolyn Shread. Cambridge: Polity, 2011.

Ontology of the Accident: An Essay on Destructive Plasticity. Trans. Carolyn Shread. Cambridge: Polity, 2012.

Marx, John. “Alien Rule." Rev. of District 9, dir. Neil Blomkamp. Safundi 11.1-2 (2010): 155-75.

Mattera, Don. Gone with the Twilight: A Story of Sophiatown. London: Zed Books, 1987.

Mbembe, Achille. "Aesthetics of Superfluity." In Mbembe and Nuttall, 37-67.

Mbembe, Achille, and Sarah Nuttall. "Introduction: Afropolis." In Mbembe and Nuttall, $1-36$.

Mbembe, Achille, and Sarah Nuttall, eds. Johannesburg: The Elusive Metropolis. Durham: Duke UP, 2008.

Modisane, Bloke. Blame Me on History. New York: Penguin, 1963.

Moele, Kgebetli. Room 207. Cape Town: Kwela, 2006.

Mohlele, Nthikeng. Small Things. Scottsville: U of KwaZulu-Natal P, 2013.

Mpe, Phaswane. Welcome to My Hillbrow. Scottsville: U of KwaZulu-Natal P, 2001. 
Mumford, Lewis. The City in History: Its Origins, Its Transformations, and Its Prospects. New York City: Harcourt, Brace, and World, 1961.

Murray, Martin J. City of Extremes: The Spatial Politics of Johannesburg. Durham: Duke UP, 2011.

Ndebele, Njabulo S. "'Iph' Indlela? Finding Our Way into the Future': The First Stephen Biko Memorial Lecture." Social Dynamics 26.1 (2000): 43-55.

Place, Rodney. "Urban Imaging: The Friche Waiting to Happen." Beautiful/Ugly: African and Diaspora Aesthetics. Ed. Sarah Nuttall. Durham: Duke UP, 2006. 317-39.

Pullman, Philip. The Golden Compass. New York: Laurel Leaf, 2002.

Quayson, Ato. “Unthinkable Nigeriana: The Social Imaginary of District 9." Johannesburg Workshop in Theory and Criticism, JWTC Blog, 16 Oct. $2009<$ http://jhbwtc.blogspot .com/2009/10/unthinkable-nigeriana-social-imaginary.html > .

Robinson, Jennifer. "(Im)mobilizing Space-Dreaming of Change." Blank_: Architecture, Apartheid, and After. Ed. Hilton Judin and Ivan Vladislavic. Rotterdam: NAi, 1998. 163-71.

Santner, Eric L. On Creaturely Life: Rilke, Benjamin, Sebald. Chicago: U of Chicago P, 2006.

Simone, AbdouMaliq. "Globalization and the Identity of African Urban Practices." Blank__: Architecture, Apartheid, and After. Ed. Hilton Judin and Ivan Vladislavic. Rotterdam: NAi, 1998. 173-87.

Sofianos, Konstantin. “Magical Nightmare Jo'burg.” Safundi 14.1 (2013): 111-20.

Stobie, Cheryl. "Dystopian Dreams from South Africa: Lauren Beukes's Moxyland and Zoo City." African Identities 10.4 (2012): 367-80.

Suvin, Darko. Metamorphoses of Science Fiction: On the Poetics and History of a Literary Genre. New Haven: Yale UP, 1979.

Themba, Can. Requiem for Sophiatown. Cape Town: Penguin Modern Classics, 2006.

Tlali, Miriam. Footprints in the Quag: Stories and Dialogues from Soweto. Cape Town, Johannesburg: David Philip, 1989.

Vladislavic, Ivan. Portrait with Keys: Joburg and What-What. Cape Town: Umuzi, 2006.

Warner, Marina. Fantastic Metamorphoses, Other Worlds: Ways of Telling the Self. Oxford: Oxford UP, 2002.

Weder, Nandi. "Space in Transition: Alternative Forms of Agency and Power in Ivan Vladislavic's Portrait with Keys." Honors thesis. U of Pretoria, 2015. 